\title{
Effects of the hydrophilic extract of Juniperus excelsa on renal function in male Wistar rats
}

\author{
Sadrollah Mehrabi ${ }^{1 *}$, Hamideh Checknezhad ${ }^{2}$, Amir Mehrabi $^{2}$, Afshin Vaziri ${ }^{1}$ \\ ${ }^{1}$ Medicinal plants Research Center, Yasuj University of Medical Sciences, Yasuj, Iran \\ ${ }^{2}$ Student research committee, Yasuj University of Medical Sciences, Yasuj, Iran
}

\section{A R T I C L E IN F O}

Article Type:

Original

\section{Article History:}

Received: 18 March 2018

Accepted: 10 July 2018

ePublished: 15 August 2018

\section{Keywords:}

Juniperus excelsa

Renal function

\begin{abstract}
A B S T R A C T
Introduction: Ores plant (Juniperus excelsa) has been used for a long-time in the treatment of kidney disease.

Objectives: The aim of this study was to investigate the effects of $J$. excelsa extract on renal function in male Wistar rats.

Materials and Methods: In this study, 32 male Wistar rats were randomly assigned into four groups of eight rats. Distilled water was used for the healthy control group and the other three groups received doses of $10 \%, 25 \%$ and $50 \%$ of the extract for one month. Prior to the intervention and on the 15th and 30th days after intervention, 24-hour urine was collected for measurement of protein, creatinine, and urine volume. On the 30th day, the rats were anesthetized with ether and in addition to the urinary samples, serum samples were taken directly from their heart to check for creatinine, urea, sodium, and potassium. Additionally, both kidneys were removed and examined for histological changes.

Results: There was a significant difference between the groups before and after intervention regarding creatinine clearance $(P=0.008)$. The mean serum urea on the 15 th and 30th days of study was respectively $93 \pm 37.33$ and $86.47 \pm 71.07 \mathrm{mg} / \mathrm{dL}(P=0.001)$. In pathology examination, minimal infiltration of inflammatory cells in the interstitium and mild decrease in thickness of renal tubules was observed in $50 \%$ dose of the extract.

Conclusion: This study showed that the greatest impact of $J$. excelsa on the renal function of the male Wistar rats was in doses of $50 \%$ of the extracts.
\end{abstract}

Implication for health policy/practice/research/medical education:

Herbal plants including the Ores plant (Juniperus excelsa) has been used for a long-time in the treatment and prevention of kidney disease. In this experimental study, we found that the greatest impact of $J$. excelsa on the renal function of male Wistar rats was in doses of $50 \%$ of the extracts.

Please cite this paper as: B. Effects of the hydrophilic extract of Juniperus excelsa on renal function in male Wistar rats. J Renal Inj Prev. 2019;8(1):34-37. DOI: 10.15171/jrip.2019.07.

\section{Introduction}

The functioning of the kidney and urinary tract is essential for the maintenance of life. The primary function of the kidneys and urinary tract is the excretion of waste materials, preservation of homeostasis by regulating body fluids and electrolytes and promoting erythropoiesis (1-6). Herbal plants including the Ores plant (Juniperus excelsa) has been used for a long-time to treat and prevent urinary tract and kidney diseases (7-9). Alpha-Pinene and limonene are the most important compounds of J. excelsa $(10,11)$. This plant grows in the Zagros mountains and has been used by native people to increase urination and treatment of kidney diseases.

\section{Objectives}

The aim of this study was to investigate the effects of the Ores extract on renal function in male Wistar rats.

\section{Materials and Methods}

Study design

In this experimental study from March to April 2016, after obtaining approval from the animal ethics committee of the university, 32 male Wistar rats with weight range between 150-200 g were selected for the study. After collecting and approving the type of plants by botanists, and determining the Herbarium number (herb \# 85), it was dried under perfect shade, powdered and the extract 
was prepared with 50\% water and 50\% alcohol and then the mixture was placed in a refrigerator and after 72 hours, it was sent to a rotary device at a temperature of $50^{\circ} \mathrm{C}$ under vacuum, condensed and dried, then maintained in the freezer. At the time of usage it was dissolved in water and alcohol. After extraction, at first, a pilot study was done with 8 rats to determine the $50 \%$ lethal dose by gavaging the first 2 rats with an undiluted extract and 3 other groups with 75,50 and $25 \%$ of the extract. Thereafter, 32 male wistar rats, were randomly assigned into four groups of eight rats. Distilled water was used for the control group and the other three groups received doses of $10 \%, 25 \%$ and $50 \%$ of the extract for 1 month. The first time was prior to the intervention and then on the 15th and 30th days after intervention, 24-hour urine was collected and protein, creatinine, urine volume and creatinine clearance were measured. On the 30th day, rats were anesthetized with ether and in addition to the tests listed above, serum samples for creatinine, urea, protein, and sodium and potassium determination were taken directly from their heart and then both kidneys were removed and sent for pathological evaluation.

\section{Ethical issues}

All experimental protocols and steps of the tests were conducted in compliance with the regulations of the research ethics committee of the university and Iranian ethical guidelines for the use of animals in research. Additionally, all animal experiments were in accordance with the protocols approved by the United States National Institutes of Health (NIH, 1978). The research was also approved by the ethics committee of Yasuj University of Medical Sciences. Prior to the experiment, the protocols were confirmed to be in accordance with the guidelines of the animal ethics committee of Yasuj University of Medical Sciences (\# 92.23.3.735).

\section{Statistical analysis}

The collected data were analyzed by SPSS software version 21. Chi-square test and analysis of variance and post hoc tests were applied to distinguish the differences between groups. The significance level was set at $0.05 \%$.

\section{Results}

Descriptive findings showed that the greatest amount of urine volume was recorded in the $50 \%$ intervention group $(0.06 \pm 7.65 \mathrm{~mL})$ (Table 1). Additionally, the mean level of urinary creatinine after intervention was $4.1 \pm 3.7 \mathrm{mmol} / \mathrm{dL}$ (Table 2). In relation to the specific gravity before and after the study, the minimum level was 1005 and the maximum was 1030. Regarding creatinine clearance, there was a significant difference between groups after intervention $(P=0.008)$. Before and after intervention $(P>0.05)$, there was no significant difference in the volume of urine protein in these rats. The mean serum urea on the 15 th and 30th days of the study was respectively $86.47 \pm 71.07 \mathrm{mg} / \mathrm{dL}$ and $93 \pm 37.33 \mathrm{mg} / \mathrm{dL}$ (Table 3). Regarding serum urea, a significant difference was detected between the groups on the 15th and 30th days of intervention as well as before and after intervention, especially in the $25 \%$ dose group $(P=0.001)$. Regarding serum total protein $(6.72 \pm 0.85$ $\mathrm{g} / \mathrm{dL})$ and mean serum creatinine $(0.87 \pm 0.22 \mathrm{mg} / \mathrm{dL})$, there were no significant differences between groups before and after intervention $(P>0.05)$. The mean level of serum $\mathrm{Na}$ on the 30 th day of study was $45.13 \mathrm{mmol} / \mathrm{dl}$ $(P=0.057)$ and the mean level of serum $\mathrm{K}$ was $4.6 \mathrm{mmol} /$ $\mathrm{dL}(P=0.067)$. In pathology, the minimal infiltration of inflammatory cells in the interstitium and mild decrease in thickness of the renal tubules was observed in 50\% dose of extract (Figure 1).

\section{Discussion}

Ores plant has 26 compounds, of which alpha-Pinene and limonene are the most important and both have

Table 1. Mean and standard deviation of urine creatinine levels at first, 15 th and $30 \mathrm{t}^{\mathrm{h}}$ days in studied groups (wistar rats)

\begin{tabular}{llccc}
\hline \multirow{2}{*}{ Group } & Number & \multicolumn{3}{c}{ Time } \\
\cline { 3 - 5 } & & Day 1 & Day 15 & Day 30 \\
\hline $\begin{array}{l}\text { Healthy } \\
\text { Control }\end{array}$ & 8 & $2.93 \pm 1.85$ & $2.21 \pm 2.52$ & $1.29 \pm 80$ \\
$10 \%$ dose & 8 & $2.38 \pm 1.53$ & $3.22 \pm 1.54$ & $3.80 \pm 1.98$ \\
$25 \%$ dose & 8 & $2.64 \pm 2.17$ & $5.08 \pm 3.49$ & $5.53 \pm 3.46$ \\
$50 \%$ dose & 8 & $3.99 \pm 1.89$ & $3.51 \pm 2.33$ & $6.47 \pm 5.21$ \\
$P$ value & & 0.06 & 0.048 & 0.28 \\
\hline
\end{tabular}

Table 2. Mean and standard deviation of urine volume levels at first, 15 th and $30 \mathrm{t}^{\mathrm{h}}$ days in studied groups (wistar rats)

\begin{tabular}{llccc}
\hline \multirow{2}{*}{ Group } & \multirow{2}{*}{ Number } & \multicolumn{3}{c}{ Time } \\
\cline { 3 - 5 } & & Day 1 & Day 15 & Day 30 \\
\hline $\begin{array}{l}\text { Healthy } \\
\text { Control }\end{array}$ & 8 & $6.25 \pm 5.49$ & $4.06 \pm 0.03$ & $4.78 \pm 1.02$ \\
$10 \%$ dose & 8 & $6.56 \pm 5.88$ & $6.81 \pm 5.61$ & $5.42 \pm 0.04$ \\
$25 \%$ dose & 8 & $5.42 \pm 4.72$ & $3.87 \pm 1.95$ & $4.59 \pm 0.01$ \\
$50 \%$ dose & 8 & $4.93 \pm 3.37$ & $3.25 \pm 2.43$ & $7.65 \pm 0.06$ \\
$P$ value & & 0.91 & 0.15 & 0.019 \\
\hline
\end{tabular}

Table 3. Mean and standard deviation of serum biochemical parameters in studied groups (Wistar rats) in 30th day ( $\mathrm{mg} / \mathrm{dL}$ )

\begin{tabular}{lccc}
\hline Group & \multicolumn{3}{c}{ Variable } \\
\cline { 2 - 4 } & $\begin{array}{c}\text { Blood urea } \\
\mathbf{m g} / \mathbf{d L}\end{array}$ & $\begin{array}{c}\text { Creatinine } \\
\mathbf{m g} / \mathbf{d L}\end{array}$ & $\begin{array}{c}\text { Total protein } \\
\mathrm{g} / \mathrm{dL}\end{array}$ \\
\hline $\begin{array}{l}\text { Healthy } \\
\text { Control }\end{array}$ & $37.46 \pm 23.38$ & $1.08 \pm 0.24$ & $16.54 \pm .06$ \\
$10 \%$ dose & $26.40 \pm 14.43$ & $0.87 \pm 0.16$ & $16.71 \pm 2.14$ \\
$25 \%$ dose & $93.86 \pm 67.80$ & $0.92 \pm 0.32$ & $12.36 \pm 2.41$ \\
$50 \%$ dose & $26.55 \pm 9.79$ & $0.87 \pm 0.22$ & $13.72 \pm 2.86$ \\
$P$ value & 0.001 & 0.35 & 0.16 \\
\hline
\end{tabular}




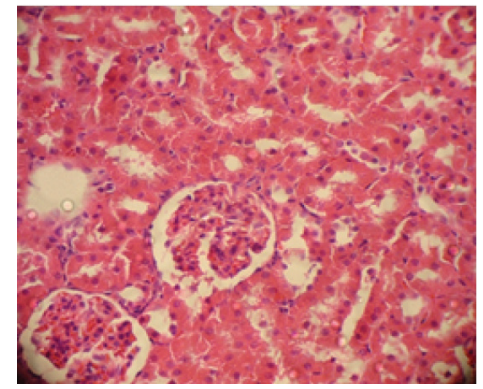

Figure 1. Photomicrograph of the kidney sections from $50 \%$ extract group that revealed minimal infiltration of inflammatory cells in interestitium and mild decrease in thickness of renal tubules (H\&E $\times 100)$.

antioxidant activity $(7,9)$. Additionally, alpha-Pinene is a potent diuretic and limonene has anti-inflammatory and analgesic effects $(7,10)$. Regarding the active compounds in the leaf and trunk of Ores, especially their effects on renal functions, we decided to evaluate the effects of extracts on renal functions in male Wistar rats. Regarding the urinary parameters of kidney functions especially, specific gravity and 24-hour urine protein before and after intervention, no significant difference was detected between the studied groups. However, significant differences were detected between groups regarding urine volume and creatinine and creatinine clearance before and after intervention, especially in doses of $25 \%$ and $50 \%$ of the extract.

In different studies, this plant has potent diuretic effects and improves edema, cardiovascular disease and salt retention (12,13). Our findings are consistent with previous studies due to increase in urine volume and urine creatinine in extract groups while no significant difference regarding serum $\mathrm{Na}$ and $\mathrm{K}$ between groups was seen. The effects of extract on serum urea on the 15th and 30 th days of intervention, especially in doses of $25 \%$ and $50 \%$ of extract are in contrast to the antioxidant effect of this plant in other studies $(8,14)$.

On the 30th day of intervention, serum urea increased significantly which indicates the harmful effects of the extract on renal function. In other studies, this plant was used for the treatment of gastrointestinal disorders, poisoning and abdominal pain in children $(8,14,15)$. In addition, its extract has antioxidant and antibacterial activity and is administered for the treatment of acne, inflammation and bacterial infection $(10,14,16)$. According to increasing urine volume and urine creatinine in our study, our results are consistent with the above studies. However, there is no comprehensive study regarding the effects of plant extracts on kidney renal function and analgesic effects of compounds present in the plant. It is expected to have protective effects and improvement of renal function, decreasing inflammation and finally, serum creatinine $(10,13,16)$. This study showed that, in doses of $50 \%$ of extract (high-dose), it had minimal inflammatory effects on renal parenchyma that are in contrast to the antioxidant effect of this plant.

\section{Conclusion}

This study showed that, the greatest impact of J. excelsa extract on the renal function of male Wistar rats was at high doses of extracts. Urine volume and creatinine increased in the intervention groups but serum urea also increased in these groups; this may be due to the harmful effects of the extract. It has no significant effect on other parameters of renal function.

\section{Acknowledgments}

We present our appreciation to respected vice president technical and research department of Yasuj University of Medical Sciences that provide the facility to perform this project by their material and ethical support. Additionally, we thank all staff of medicinal plants research center and animal lab of Yasuj University of medical sciences who assisted us in performing this project.

\section{Authors' contribution}

SM; the concept, design, data analysis, and manuscript preparation ,manuscript review and final revision. HC; performing experiments, data collection and writing proposal. AM; data collection and providing first draft and submission. AV; statistical analysis, data collection and first revision. All authors read and signed the final paper.

\section{Conflicts of interest}

The authors declared no conflicts of interest.

\section{Ethical considerations}

Ethical issues (including plagiarism, data fabrication, double publication) have been completely observed by the authors.

\section{Funding/Support}

This manuscript extracted from a project with code number P.23.15.851,that supported financially by deputy of research of Yasuj University of Medical Sciences.

\section{References}

1. Stoller M. Urinary stone disease. In: Tanago EA, McAninch JW, eds. Smith's General Urology. 17th ed. New York: McGraw-Hill Medical; 2008 p. 28-118.

2. Marshall JR. The Comparative physiology of the kidney in relation to theories of renal secretion. Physiol Rev. 1934; 14: 133-159.doi.org/10.1152/physrev.1934.14.1.133

3. Hemmelgarn BR, Manns BJ, Lloyd A, James MT, Klarenbach S, Quinn RR, et al. Alberta Kidney Disease Network. Relation between kidney function, proteinuria, and adverse outcomes. JAMA. 2010 Feb 3; 303:423-9. doi: 10.1001/jama.2010.39.

4. Kosmadakis G, Filiopoulos V, Georgoulias C, Smirloglou D, Draganis T, Michail S. Quantitative evaluation of proteinuria by estimation of the protein/creatinine ratio 
in a random urine sample. Ren Fail. 2010;32:153-6. doi: 10.3109/08860220903491208.

5. Kim SY, Moon A. Drug-induced nephrotoxicity and its biomarkers. Biomol Ther (Seoul). 2012;20:268-72. doi: 10.4062/biomolther.2012.20.3.268.

6. Mehrabi S, Ghafarian Shirhzi HR, Rasti M. Normal serum prostate specific antigen levels in men in Yasuj province, Islamic Republic of Iran. East Mediterr Health J. 2007; 13:1190-4.

7. 7.Salehi Shanjani P, Mirza M. Seasonal variation of the leaf and cone oil of Juniperus excels M.B. J Med Plant. 2006; 1:50-58

8. Cai, Y. Luo, Q. Sun. M. Corke, H. Antioxidant activity and phenolic compounds of 112 traditional Chinese medicinal plants associated with anticancer. Life Sci. 2004;74: $2157-$ 2184. doi: 10.1016/j.lfs.2003.09.047

9. Vahdani R, Mehrabi S, Malekzadeh J, Sadeghi H, Jannesar R, Mehrabi F. Effects of hydrophilic extract of Allium jesdianum on prevention and treatment of ethylene glycol induced renal stone in male Wistar rats. Life Sci J. 2013;10:17-21

10. Sela F, Karapandzova M, Stefkov G, Cvetkovikj I, Kulevanova S. Chemical composition and antimicrobial activity of essential oils of Juniperus excelsa Bieb. (Cupressaceae) grown in R. Macedonia. Pharmacognosy Res. 2015;7:74-80. doi: $10.4103 / 0974-8490.147212$.
11. Ahmed M, Shaukat SS, Buzdar AH Population structure and dynamics of Juniperus excelsa in Baluchistan, Pakistan. J Veg Sci.1999;1:271-276 doi: 10.2307/3235664.

12. Khan M, Khan AU, Najeeb-ur-Rehman, Zafar MA, Hazrat A, Gilani AH. Cardiovascular effects of Juniperus excelsa are mediated through multiple pathways. Clin Exp Hypertens. 2012; 34:209-16. doi: 10.3109/10641963.2011.631651.

13. Samoylenko V, Dunbar DC, Gafur MA, Khan SI, Ross SA, Mossa JS, El-Feraly FS, Tekwani BL, Bosselaers J, Muhammad I. Antiparasitic, nematicidal and antifouling constituents from Juniperus berries. Phytother Res. 2008; 22:1570-6. doi: 10.1002/ptr.2460

14. Hosseinihashemi SK, Dadpour A, Lashgari A. Antioxidant activity and chemical composition of Juniperus excelsa ssp. polycarpos wood extracts. Nat Prod Res. 2017;31:681-685. doi: 10.1080/14786419.2016.1209666.

15. Khan M, Khan AA, Rehman NU, Gilani AH. P pharmacological ex planation for the medicinal use of Juniperus excelsa in hyperactive gastrointestinal and respiratory disorders. J Nat Med. 2012;66:292-301.

16. Moein MR, Ghasemi Y, Moein S, Nejati M. Analysis of antimicrobial, antifungal and antioxidant activities of Juniperus excelsa M. B subsp. Polycarpos (K. Koch) Takhtajan essential oil. Pharmacognosy Res. 2010;2:128-31. doi: $\quad$ 10.4103/0974-8490.65505.

Copyright (c) 2019 The Author(s); Published by Nickan Research Institute. This is an open-access article distributed under the terms of the Creative Commons Attribution License (http://creativecommons.org/licenses/by/4.0), which permits unrestricted use, distribution, and reproduction in any medium, provided the original work is properly cited. 